\title{
PARTISIPASI MASYARAKAT LOKAL DALAM PENGELOLAAN USAHA WISATA DI KOTA SENTANI, KABUPATEN JAYAPURA, PAPUA
}

\author{
Nani Eunike Manoach ${ }^{1}$, IGPB. Sasrawan Mananda ${ }^{2}$, I Nyoman Sudiarta ${ }^{3}$ \\ Email:nany_eunike@yahoo.com ${ }^{1}$, gusmananda@unud.ac.id ${ }^{2}$, sudiarta.nyoman@yahoo.co.id ${ }^{3}$ \\ ${ }^{1,2,3}$ Program Studi Industri Perjalanan Wisata, Fakultas Pariwisata, Universitas Udayana
}

\begin{abstract}
Local community participation in managing of local industry is important to tourism development in Sentani City, Jayapura Regency, Papua. The purpose of this study is to determine the participation of local community in the tourism industry entrepreneurship in Sentani City. The informant determination technique used in this research was purposive technique and the data analyze technique used in research was qualitative descriptive. The study result showed that local people in Sentani, have impulsive participation in tourist attraction business, waterpark, rent boats, and handycraft business. Coersive participation in rent car business, tour and travel, restaurant, and accommodation business. Induced participation in tour guide business.
\end{abstract}

Abstrak: Partisipasi masyarakat lokal dalam pengelolaan usaha wisata sangat penting untuk pengembangan pariwisata di Kota Sentani, Kabupaten Jayapura, Papua. Penelitian ini bertujuan untuk mengetahui bentuk partisipasi masyarakat lokal dalam pengelolaan usaha-usaha wisata di Kota Sentani. Teknik penentuan informan dalam penelitian ini menggunakan teknik purposif. Teknik analisis data dalam penelitian ini menggunakan teknik analisis deskriptif kualitatif. Berdasarkan hasil penelitian didapatkan, bahwa masyarakat lokal di Kota Sentani, berpartisipasi spontan dalam usaha daya tarik wisata, wisata tirta, penyewaan perahu dan dalam usaha kerajinan tangan. Berpartisipasi paksaan dalam usaha penyewaan mobil, jasa perjalanan wisata, jasa makanan dan minuman dan penyediaan akomodasi. Berpartisipasi terdorong dalam usaha jasa pramuwisata.

Keywords: community participation, entrepreneurship, sentani, tourism industry.

\section{PENDAHULUAN}

Kecenderungan baru perkembangan pariwisata internasional memiliki perubahan pada dimensi industri pariwisata internasional antara lain: perubahan lingkungan ekonomi dan politik global, perubahan profil demografis dan psikografis wisatawan internasional, perubahan manajemen pariwisata, dan perubahan teknologi pariwisata. Hal ini berarti bahwa bila selama ini masyarakat lebih banyak di tuntut untuk menjadi tuan rumah yang baik dengan perolehan keuntungan yang tidak seimbang dihadapan wisatawan maupun pengusaha besar (Lea , 1988; Shaw dan William,1994; Pierce, Cohen, Rilley, Simmel dalam Theobald ed., 1994), sekarang ini kecenderungan baru perkembangan pariwisata di tuntut pula untuk memberikan peluang bagi pembagian keuntungan dan kerugian yang lebih adil, termasuk didalamnya tuntutan masyarakat sebagai pelaku sosial yang memiliki hak berwisata dan dengan demikian memiliki hak memperoleh pelayanan dari pembangunan kepariwisataan.

Partisipasi masyarakat dalam pengembangan pariwisata di Indonesia terlihat dibeberapa daya tarik wisata di Indonesia. Masyarakat dilibatkan dalam pengelolaan dan pengembangan suatu daya tarik wisata, guna untuk membantu meningkatkan ekonomi masyarakat lokal setempat. Salah satu kabupaten di Indonesia yang sedang berkembang pariwisata nya adalah Kabupaten Jayapura. Di Kabupaten Jayapura terdapat banyak potensi dan daya tarik yang di kembangkan untuk meningkatkan kesejahteraan masyarakat, ada wisata alam dan budaya yang dikembangkan menjadi daya tarik tersendiri bagi Kabupaten Jayapura. Untuk itu dibutuhkan industri pariwisata dalam menunjang pengembangan pariwisata yang ada di Kabupaten Jayapura. Industri pariwisata di Kabupaten Jayapura telah ada 
dan terus berkembang. Jumlah industri pariwisata yang berada di Kota Sentani juga senantiasa berkembang. Keberadaan industri pariwisata di Kota Sentani ini adalah sebagai pendukung dalam memberikan layanan yang baik kepada wisatawan yang berkunjung ke Kota Sentani. Potensi pariwisata alam dan budaya yang ada di Kabupaten Jayapura khususnya di Kota Sentani ini menjadi faktor penarik terbesar bagi wisatawan untuk datang berkunjung ke Kota Sentani dan ini merupakan peluang bagi masyarakat untuk mengembangkan usaha wisata di Kabupaten Jayapura, khususnya Kota Sentani.

\section{METODE PENELITIAN}

Studi ini dilakukan untuk mengetahui partisipasi masyarakat lokal dalam pengelolaan usaha wisata di Kota Sentani, Kabupaten Jayapura, Papua. Variabel yang digunakan adalah variabel partisipasi masyarakat serta variabel usaha wisata. Untuk mendapatkan data dalam studi ini digunakan beberapa teknik pengumpulan data antara lain: observasi, wawancara mendalam, studi kepustakaan, dokumentasi.

Teknik analisis data yang digunakan pada studi ini adalah analisis deskriptif kualitatif. Metode ini dilakukan untuk mendeskripsikan atau menggambarkan dengan jelas dan objektif mengenai Partisipasi Masyarakat Lokal dalam Pengelolaan Usaha Wisata di Kota Sentani Kabupaten Jayapura, Provinsi Papua.

\section{HASIL DAN PEMBAHASAN}

Kota Sentani memiliki luas $79,8 \mathrm{Km}^{2}$ dan berbatasan dengan sebelah Utara Gunung Cyclop, sebelah selatan Distrik Ebungfau, sebelah barat Distrik Waibu dan sebelah Timur Distrik Sentani Timur. Jumlah penduduk Kota Sentani pada tahun 2017 berjumlah 81.776 jiwa. Penduduk laki-laki merupakan Populasi terbesar yaitu 43.536 Jiwa, sedangkan penduduk perempuan berjumlah 38.240. Produksi komoditas tanaman pangan selama tahun 2017 diantaranya Jagung, Ubi Kayu dan Ubi jalar. Produksi komoditas sayur-sayuran yang dihasilkan selama tahun 2017 diantaranya cabe merah, sawi, tomat, kangkung dan bayam. Sarana angkutan umum per kampung di Kota Sentani adalah mobil dan motor ojek. Sarana angkutan jenis perahu tradisional dan speed boat hanya terdapat di Kampung Hobong, Ifale, Dobonsolo dan Ifar Besar. Sedangkan sinyal telekomunikasi di masing-masing kampung di Kota Sentani sangat baik. Adapun daya Tarik wisata di Kota Sentani berupa:

\section{Danau Sentani}

Danau Sentani merupakan danau terbesar di Provinsi Papua, danau ini memiliki luas sekitar 9.360 hektar dan berada pada ketinggian 75 mdpl. Danau Sentani juga merupakan danau terbesar kedua di Indonesia setelah Danau Toba. Terdapat 21 gugusan pulau yang tersebar di tiga wilayah danau, yaitu Sentani Tengah, Barat dan Timur.

2. Bukit Teletubies

Terletak di Kampung Doyo Sentani, Bukit Teletubies merupakan sebuah jajaran bukit yang panjang dan luas yang berada tepat di tepi Danau Sentani. Lokasi nya yang strategis ini menawarkan pemandangan yang sangat indah, hal ini menjadi daya tarik tersendiri bagi wisatawan untuk berkunjung dan mengambil gambar. Untuk dapat sampai ke Bukit Teletubies dibutuhkan waktu kurang lebih 20 menit dari bandara Sentani.

3. Danau Love

Danau Love merupakan sebuah telaga kecil atau danau kecil yang berbentuk hati.

Danau ini terletak di Kecamatan Ebungfau, Kabupaten Jayapura, penduduk setempat menyebutnya sebagai Danau Emfote berdasarkan nama tempatnya. Danau berbentuk hati yang indah akan tampak jelas dilihat dari bukit yang ada disekelilingnya. Dari atas bukit ini juga merupakan tempat terbaik untuk mengambil foto dengan latar belakang danaunya.

4. Air Terjun Harapan

Terletak di kampung Nolokla, Distrik Sentani Timur, Air Terjun ini juga merupakan daya tarik wisata yang ada di Kabupaten Jayapura. Letaknya di pegunungan menjadi tantangan tersendiri bagi wisatawan untuk dapat menikmati wisata adventure. Untuk dapat sampai ke air terjun ini dibutuhkan waktu sekitar 20 menit dari Bandara Sentani dan dibutuhkan waktu kurang lebih satu jam untuk trekking agar dapat sampai ke air terjun ini.

5. Desa Wisata Asei 
Desa Wisata Asei terletak di Distrik Sentani Timur, Kabupaten Jayapura. Desa ini merupakan desa yang terkenal dengan kerajinan tangan masyarkat lokalnya yaitu, lukisan kulit kayu. Selain itu di Desa Wisata Asei juga terdapat sebuah gereja tua yang telah ada sejak tahun 1930, gereja ini kemudian menjadi daya tarik bagi pengunjung yang datang ke Desa Wisata Asei. Desa Wisata Asei adalah sebuah pulau kecil yang berada di Danau Sentani, hal ini membuat Desa Wisata Asei memiliki pemandangan alam sekitar yang sangat indah.

6. Tugu Mac Arthur

Tugu Mac Arthur tepat menghadap Kota Sentani. Masyarakat sekitar kerap menyebutnya Makatur, sama seperti penyebutan Siklop untuk Cycloop. Di tugu bersegi lima bercat kuning hitam itu, tersembul gambar anak panah dan pedang yang menyilang. Ada separagraf kalimat berbahasa Indonesia dan Inggris yang terukir, sebagai penjelasan singkat tentang Markas Besar Umum Pasifik Barat Daya. Ada sebuah bangunan kecil di samping tugu. Di sana jadi tempat informasi jejakjejak jenderal Douglas MacArthur dari Amerika Serikat itu, lengkap dengan fotofoto dokumentasinya.

\section{Partisipasi Masyarakat Lokal dalam Pegelolaan Usaha Wisata Di Kota Sentani Daya Tarik Wisata}

Kota Sentani memiliki tujuh daya tarik wisata, yang adalah empat wisata alam, satu wisata budaya, satu wisata sejarah dan satu wisata tirta. Dua wisata alam, satu wisata budaya dan satu wisata tirta dikelola oleh masyarakat lokal. Hal ini berarti sekitar 57\% daya tarik wisata di Kota Sentani di kelola oleh masyarakat lokal. Berdasarkan pada tahapan partisipasi, pada tahap pengambilan keputusan dapat diketahui bahwa masyarakat lokal yang berdomisili di sekitar daya tarik wisata ini melakukan partisipasi spontan yaitu, masyarakatnya terlibat didalam suatu keputusan. Dalam hal pengambilan keputusan ini, masyarakat berpartisipasi langsung dalam mengambil keputusan untuk mengelola daya tarik wisata yang ada di daerahnya. Daya tarik wisata tersebut ialah daya tarik wisata Danau Love, Bukit Teletubies dan Desa Wisata Asei. Hingga saat ini pengelolaan daya tarik wisata ini masih dikelola oleh masyarakat lokal setempat. Pada awalnya masyarakat lokal belum menyadari tentang potensi wisata alam yang ada di daerah mereka. Hingga adanya kunjungan wisatawan lokal dan semakin hari semakin meningkat. Dengan adanya wisatawan yang berkunjung, membuat masyarakat lokal akhirnya memutuskan untuk memulai pengelolaan daya tarik wisata dengan diawali dengan kegiatan pembersihan lokasi daya tarik wisata. Pada tahapan pelaksanaan, masyarakat lokal melakukan partisipasi spontan yaitu, masyarakat lokal memiliki kesempatan untuk berpartisipasi langsung dalam menjaga daya tarik wisata yang ada di daerahnya. Dalam pengelolaan daya tarik wisata yang ada di Kota Sentani, masyarakat lokal diberikan kesempatan untuk mengelola sendiri daya tarik wisata yang ada di daerah mereka. Pada tahapan pengambilan pemanfaatan, masyarakat lokal melakukan partisipasi spontan yaitu, partisipasi yang dilakukan secara langsung. Partipasi yang muncul telah ada bersifat bottom-up, partispasi aktif dan termasuk partisipasi asli. Dalam hal pengambilan pemanfaatan, partisipasi yang dilakukan masyarakat lokal adalah partisipasi langsung yang mana masyarakat lokal sentani membuat pondok-pondok untuk berjualan makanan dan minuman di kawasan daya tarik wisata yang ada di Kota Sentani, selain itu masyarakat lokal juga membuat kerajinan tangan khas daerah nya untuk kemudian dipasarkan di daya tarik wisata yang ada di daerah mereka. Pada tahapan evaluasi, partisipasi masyarakat berada pada tahapan partisipasi terdorong (induced participation) yaitu, partisipasi terdapat alternative pilihan dari suatu usulan yang telah ditawarkan dan mendapatkan feedback dari masyarakat. Dalam tahap evaluasi mengenai pengembangan daya tarik wisata yang ada, masyarakat lokal di sekitar daya tarik wisata diberikan usulan mengenai pengelolaan daya tarik wisata yang baik dari pemerintah. Masyarakat lokal setempat kemudian menerima dan meminta bantuan pemerintah untuk ikut membantu pengembangan daya tarik wisata yang ada di Kota Sentani khususnya di Daya Tarik Wisata Danau Love, Bukit Teletubies dan Desa Wisata Asei.

\section{Wisata Tirta}

Berdasarkan hasil wawancara dengan Bapak Pendiun (staf Cycklop Waterpark), dapat diketahui bahwa dalam usaha wisata tirta 
pada tahap pengambilan keputusan, masyarakat lokal melakukan partisipasi spontan yaitu, masyarakat lokal memiliki kesempatan untuk ikut serta dalam perencanaan dan bertanggung jawab dalam menjalalankan usaha yang dimulai nya. Dalam usaha wisata tirta di Kota Sentani, pada tahap pengambilan keputusan, masyarakat memiliki kebebasan dalam mengambil keputusan untuk merencanakan dan menjalankan usaha dalam bidang wisata tirta. Pada tahap pelaksanaan, masyarakat lokal melakukan partisipasi spontan yaitu, partisipasi dilakukan secara langsung. Partisipasi yang muncul telah ada bersifat bottom-up, partispasi aktif dan termasuk partisipasi asli. Dalam tahap pelaksanaan, dapat diketahui masyarakat lokal berpartisipasi langsung dalam memulai dan menjalankan usaha wisata tirta di Kota Sentani. Setelah merencanakan, masyarakat lokal kemudian melaksanakan rencananya, dengan membuka usaha wisata Tirta di Kota Sentani. Hal ini dilakukan dengan modal pribadi dan tanpa bantuan dari pihak lain. Pada tahap pengambilan pemanfaatan dalam usaha wisata tirta dapat diketahui bahwa masyarakat lokal berpartisipasi spontan yaitu, Partisipasi dilakukan secara langsung. Partisipasi yang muncul telah ada bersifat bottom-up, partisipasi aktif dan termasuk partisipasi asli. Partisipasi masyarakat lokal dalam usaha wisata tirta pada pengambilan pemanfaatan yaitu, masyarakat lokal berpartisipasi aktif dalam memanfaatkan potensi wisata yang ada di daerahnya dan kemudian dijadikan usaha wisata tirta. Usaha wisata tirta ini kemudian menjadi usaha wisata tirta pertama yang ada di Kota Sentani dan dikelola oleh masyarakat lokal. Pada tahap evaluasi dalam usaha wisata tirta, dapat diketahui bahwa masyarakat lokal berpartisipasi terdorong (induced participation) yaitu, partisipasi terdapat alternative pilihan dari suatu usulan yang telah ditawarkan dan mendapatkan feedback dari masyarakat. Pada tahap evaluasi dalam usaha wisata tirta dapat diketahui bahwa masyarakat lokal mendapatkan saran dan usulan dari pihak pemerintah untuk tetap berpartisipasi dalam menjalankan dan mengembangkan wisata tirta yang ada di Kota Sentani. Di harapkan masyarkat lokal lainnya juga dapat ikut berpartisipasi dalam memanfaatkan potensi wisata yang ada. Hal ini diterima baik oleh masyarakat lokal.

\section{Jasa Transportasi Wisata}

Kota Sentani memiliki dua jenis jasa transportasi wisata yang adalah rent boat dan rent car. Pada usaha rent car yang berjumlah kurang lebih tiga puluh mobil dan delapan diantaranya dimiliki oleh masyarakat lokal, hal ini menunjukan bahwa terdapat $26 \%$ usaha rent car yang dijalankan oleh masyarakat lokal. Pada usaha rent boat seluruh nya $100 \%$ dikelola oleh masyarakat lokal itu sendiri. Berdasarkan dari penjelasan Bapak Karel Tokoro (pemilik mobil yang di sewakan), dapat diketahui bahwa tahapan partisipasi masyarakat lokal pada tahap pengambilan keputusan dalam usaha rent car adalah partisipasi spontan yaitu, partisipasi dilakukan secara langsung. Partisipasi yang muncul telah ada dan bersifat bottom-up, partisipasi aktif dan termasuk partisipasi asli. Masyarakat lokal mengambil partisipasinya secara langsung yaitu memutuskan untuk menyewakan mobil pribadinya untuk sewa oleh wisatawan. Pada tahap pelaksanaan, masyarakat lokal melakukan partisipasi paksaan (Coersive Participation) yaitu, partisipasi yang sangat terasa dominasi pihak luar lebih unggul daripada masyarakat setempat (paternalism). Dari hasil observasi dan wawancara yang telah dilakukan dapat diketahui bahwa dalam usaha rent car di Kota Sentani lebih didominasi oleh masyarakat pendatang dan bukan masyarakat lokal Kota Sentani. Hal ini dapat dilihat dari jumlah mobil dan pengemudi nya yang ada di pangkalan mobil (tempat penyewaan mobil). Pada tahap pengambilan pemanfaatan, masyarakat lokal melakukan partisipasi paksaan (Coersive Participation), partisipasi yang terjadi pada umumnya terjadi secara tidak langsung. Dalam hal pengambilan pemanfaatan, partisipasi yang dilakukan masyarakat lokal merupakan partisipasi yang dilakukan secara tidak langsung atau diwakilkan. Partisipasi yang diwakilkan ini terlihat dalam pengambilan pemanfaatan usaha rent car, dimana tidak banyak masyarakat lokal yang menyewakan mobil pribadi, tetapi justru hal ini dilakukan oleh masyarakat pendatang yang berdomisili di Kota Sentani dan sekitarnya. Masyarakat lokal lebih memilih menggunakan mobil pribadinya untuk digunakan dalam aktivitas sehari-hari. Dimana masyarakat lokal di Kota Sentani yang memiliki mobil adalah masyarakat lokal yang berprofesi sebagai Pegawai Negeri Sipil (PNS). Pada tahap evaluasi, masyarakat lokal 
melakukan partisipasi terdorong (Induced Participation) yaitu, partisipasi terdapat alternative pilihan dari suatu usulan yang telah ditawarkan dan mendapatkan feedback dari masyarakat. Dalam tahap evaluasi, masyarakat lokal di ingatkan untuk dapat mengambil bagian dalam usaha rent car, sehingga tidak semuanya didominasi oleh masyarakat pendatang. Selain akan dapat memberikan penambahan pemasukan, usaha ini juga dapat membantu mengembangkan industri pariwisata di Kota Sentani. Berdasarkan hasil penjelasan dari Bapak Andi Sokoy(pemilik usaha rentboat), dapat diketahui bahwa dalam usaha rent boat, pada tahap pengambilan keputusan masyarakat lokal sentani melakukan partisipasi spontan yaitu, masyarakat lokal memiliki kesempatan untuk melakukan perencanaan dan bertanggung jawab mengatur usaha yang ingin mereka jalankan. Pada tahap pengambilan keputusan dalam usaha jasa transportasi wisata rent boat, masyarakat lokal merencanakan dan memillih sendiri untuk menjalankan usaha dalam bidang jasa transportasi wisata rent boat di kawasan Danau Sentani. Keputusan ini diambil berdasarkan inisiatif sendiri pada saat melihat peluang yang ada dan tanpa adanya paksaan dari pihak lain. Pada tahap pelaksanaan masyarakat lokal melakukan partisipasi spontan yaitu, partisipasi dilakukan secara langsung. Partisipasi yang muncul telah ada bersifat bottom-up, partisipasi aktif dan termasuk partisipasi asli. Pada partisipasi ini, masyarakat menjalankan usaha nya secara baik dan tanpa diwakilkan oleh luar. Masyarakat lokal sendiri yang merencanakan dan menjalankan usahanya dan tidak di intenfensi dari pihak-pihak lain. Pada tahap pengambilan pemanfaatan dalam usaha rent boat, masyarakat lokal melakukan partisipasi spontan yaitu, Partisipasi dilakukan secara langsung. Partisipasi yang muncul telah ada bersifat bottom-up, partispasi aktif dan termasuk partisipasi asli. Dalam tahap pengambilan pemanfaatan, masyarakat lokal berpatisipasi langsung dalam memanfaatkan peluang kunjungan wisatawan ke Danau Sentani. Masyarakat lokal yang mempunyai perahu tradisional maupun speedboat kemudian menggunakannya untuk menjadi jasa transportasi wisata di kawasan daya tarik wisata Danau Sentani. Pada tahap evaluasi dalam usaha rent boat, masyarakat lokal melakukan partisipasi spontan yaitu, masyarakat lokal memiliki kesempatan untuk melakukan perencanaan dan bertanggung jawab mengatur serta memiliki wewenang sepenuhnya. Dalam tahap evaluasi, bentuk partisipasi masyarakat lokal dalam usaha rent boat terlihat sangat baik dan masyarakat lokal mempunyai hak penuh untuk tetap mengembangkan usaha jasa transportasi wisata rent boat di kawasan daya tarik wisata Danau Sentani.

\section{Jasa Perjalanan Wisata}

Kota Sentani memiliki biro perjalanan/travel yang berjumlah empat dan satu (25\%) di antaranya adalah milik masyarakat lokal. Berdasarkan pada hasil wawancara dengan Bapak Demianus Wasage (pemilik usaha travel) dapat diketahui bahwa dalam usaha jasa perjalanan wisata, pada tahap pengambilan keputusan masyarakat lokal melakukan partisipasi spontan yaitu, masyarakat lokal memiliki kesempatan untuk melakukan perencanaan dan bertanggung jawab mengatur usahanya. Dalam tahap pengambilan keputusan, masyarakat berpartisipasi langsung dalam menyusun rencana usaha nya dan kemudian mengambil keputusan untuk memulai usaha nya dalam bidang jasa perjalanan wisata, tanpa ada paksaaan dari pihak lain. Pada tahap pelaksanaan masyarakat lokal melakukan partisipasi partisipasi paksaan (Coersive Participation) yaitu, partisipasi yang sangat terasa dominasi pihak luar lebih unggul dari pada masyarakat setempat (paternalism). Dalam hal pelaksanaan usaha jasa perjalanan wisata di Kota Sentani, terdapat empat jasa perjalanan wisata yang masih aktif dan hanya satu jasa perjalanan wisata yang di kelola oleh masyarakat lokal, sedangkan sisa nya dikelola oleh masyarakat pendatang. Pada tahap pengambilan pemanfaatan, masyarakat lokal melakukan partisipasi paksaan (Coersive Participation) yaitu, partisipasi yang terjadi pada umumnya terjadi secara tidak langsung. Dalam hal pengambilan pemanfaatan dalam usaha perjalanan jasa wisata di Kota Sentani, partisipasi masyarakat lokal sangat kurang. Dalam hal ini masyarakat lokal tidak berpartisipasi secara langsung. Partisipasi masyarakat lokal dalam usaha ini di wakilkan oleh masyarakat pendatang. Yang mana usaha perjalanan wisata di Kota Sentani di dominasi oleh pengusaha yang berasal dari luar Provinsi Papua dan bukan masyarakat lokal Sentani. 
Pada tahap evaluasi, masyarakat lokal melakukan partisipasi terdorong (Induced Participation) yaitu, partisipasi terdapat alternative pilihan dari suatu usulan yang telah ditawarkan dan mendapatkan feedback dari masyarakat. Dalam tahap evaluasi, masyarakat lokal diminta untuk menyadari akan kurangnya partisipasi masyarakat dalam usaha jasa perjalanan wisata di Kota Sentani. Masyarakat lokal telah melihat dan mendengar banyak saran mengenai usaha perjalanan wisata di Kota Sentani namun belum banyak masyarakat lokal yang ingin memulai usaha dalam bidang tersebut dikarenakan masih kurang nya pengetahuan dalam pengelolaan usaha perjalanan wisata.

\section{Jasa Makanan dan Minuman}

Restaurant yang berada di Kota Sentani berjumlah tiga puluh dan hanya satu di antaranya yang dimiliki oleh masyarakat lokal. Hal ini menunjukan bahwa hanya terdapat $3.3 \%$ usaha restaurant yang dimiliki oleh masyarakat lokal yang berada di Kota Sentani. Berdasarkan hasil wawancara (Juni 2019) dengan Ibu Vonny (pemilik restaurant Asei Faa), dapat diketahui bahwa dalam usaha restaurant, pada tahap pengambilan keputusan masyarakat lokal melakukan partisipasi spontan yaitu, masyarakat lokal memiliki kesempatan untuk melakukan perencanaan dan bertanggung jawab mengatur usahanya. Dalam usaha restaurant di Kota Sentani dan dalam tahap pengambilan keputusan, masyarakat lokal memiliki hak sepenuhnya untuk mengambil keputusan dalam merencanakan, membuka dan menjalankan usaha restaurant di Kota Sentani. Pada tahap pelaksanaan, masyarakat lokal melakukan partisipasi paksaan (coersive participation) yaitu, partisipasi yang sangat terasa dominasi pihak luar lebih unggul daripada masyarkat setempat (paternalism). Dalam hal pelaksanaan usaha jasa makanan dan minuman (restaurant) di Kota Sentani, dapat diketahui bahwa hanya terdapat satu restaurant yang dikelola oleh masyarakat lokal, dan sisa nya dikelola oleh masyarakat pendatang. Pada tahap pengambilan pemanfaatan, dapat diketahui bahwa masyarakat lokal melakukan partisipasi paksaan (Coersive Participation) yaitu, partisipasi yang terjadi pada umumnya terjadi secara tidak langsung. Dalam tahap pengambilan pemanfaatan, masyarakat lokal tidak berpartisipasi secara langsung.
Partisipasi masyarakat lokal diwakilkan dengan partisipasi dari masyarakat pendatang, yang mana pemilik usaha jasa makanan dan minuman di Kota Sentani lebih di dominasi oleh masyarakat pendatang. Masyarakat lokal terlihat kurang memanfaatkan potensi yang di Kota Sentani, untuk membuka usaha jasa makanan dan minuman sehingga terlebih dahulu didominasi oleh masyarakat pendatang. Pada tahap evaluasi dalam usaha jasa makanan dan minuman, masyarakat lokal melakukan partisipasi terdorong (induced participation) yaitu, Partisipasi terdapat alternative pilihan dari suatu usulan yang telah ditawarkan dan mendapatkan feedback dari masyarakat. Dalam tahap evaluasi, masyarakat lokal diberikan saran dan usulan untuk dapat memanfaatkan situasi dan kondisi yang ada di Kota Sentani untuk dapat membuka usaha jasa makanan dan minuman. Masyarakat lokal mendengar dan menerima dengan baik usulan dan saran yang di berikan. Namun belum semuanya berani untuk memulai usaha dalam bidang jasa makanan dan minuman tersebut, dikarenakan belum mempunyai modal yang cukup.

\section{Penyediaan Akomodasi}

Jumlah Hotel di Kota Sentani adalah berjumlah tujuh belas dan tiga di antaranya adalah milik masyarakat lokal, yang berarti hanya berkisar sekitar $17 \%$ hotel yang dimiliki oleh masyarakat lokal. Berdasarkan pada hasil wawancara (Juni 2019) dari ke tiga narasumber, Bapak Bilce Mehue (pemilik hotel Ariyauw Perkasa), Ibu Yuliana Rumbekwan (pemilik hotel Mansarpurani), Bapak Pendiun (Staf Hotel Cyklop) dapat diketahui bahwa partisipasi masyarakat dalam usaha penyediaan akomodasi pada tahap pengambilan keputusan, masyarakat lokal melakukan partisipasi spontan yaitu, masyarakat lokal memiliki kesempatan untuk melakukan perencanaan dan bertanggung jawab mengatur serta memiliki wewenang sepenuhnya. Masyarakat lokal memiliki kebebasan dalam mengambil keputusan untuk merencanakan, memulai dan menjalankan usaha nya dalam bidang penyediaan akomodasi di Kota Sentani. Pada tahap pelaksanaan masyarakat lokal melakukan partisipasi paksaan (coersive participation) yaitu, partisipasi yang sangat terasa dominasi pihak luar lebih unggul dibandingkan masyarakat setempat (paternalism). Dari hasil 
observasi dan wawancara di lapangan dari tujuh belas usaha penyediaan akomodasi yang ada di Kota Sentani tercatat hanya ada tiga usaha penyediaan akomodasi yang di miliki oleh masyarakat lokal. Masyarakat pendatang lebih mendominasi dalam menjalankan usaha penyediaan akomodasi di Kota Sentani. Pada tahap pengambilan pemanfaatan dalam usaha penyediaan akomodasi, masyarakat lokal melakukan partisipasi paksaan (coersive participation) yaitu, partisipasi yang terjadi pada umumnya terjadi secara tidak langsung. Dalam usaha penyediaan akomodasi, partisipasi masyarakat lokal diwakili oleh partisipasi masyarakat pendatang. Dalam tahap pengambilan pemanfaatan, masyarakat pendatang lebih berpartisipasi dalam memanfaatkan kesempatan yang ada untuk menjalankan usaha penyediaan akomodasi di Kota Sentani. Masyarakat lokal kurang berpartisipasi dalam pengembangan usaha penyediaan akomodasi di Kota Sentani, faktor utamanya dikarenakan kekurangan modal dalam memulai usaha. Pada tahap evaluasi, masyarakat lokal melakukan partisipasi terdorong (induced participation) yaitu, terdapat alternatif pilihan dari suatu usulan yang telah ditawarkan dan mendapatkan feedback dari masyarakat. Pada tahap evaluasi usaha penyediaan akomodasi, masyarakat lokal mendapatkan saran dan usulan untuk dapat berpartisipasi dalam menjalankan usaha penyediaan akomodasi di Kota Sentani. Masyarakat lokal menerimanya dengan baik dan mulai tertarik untuk membuka usaha penyediaan akomodasi namun masih terbatas dengan modal usaha.

\section{Jasa Pramuwisata}

Berdasarkan hasil wawancara dengan Bapak Niki Mehue (Ketua Himpunan Pramuwisata Indonesia Kabupaten Jayapura Juni 2019), dapat diketahui bahwa dalam usaha jasa pramuwisata pada tahap pengambilan keputusan, masyarakat lokal melakukan partisipasi terdorong (induced participation) yaitu, terdapat alternatif pilihan dari suatu usulan yang telah ditawarkan dan mendapatkan feedback dari masyarakat. Dalam usaha jasa pramuwisata pada tahap pengambilan keputusan dapat diketahui bahwa masyarakat lokal diberikan usulan bahkan pelatihan pemandu wisata dari pemerintah. Diharapkan masyarakat lokal dapat berpartisipasi dalam menyediakan jasa pramuwisata di Kota Sentani. Dalam tahap pengambilan keputusan ini, hanya beberapa masyarakat saja yang tertarik dan terus bekerja sebagai pramuwisata di Kota Sentani. Pada tahap pelaksanaan, masyarakat lokal melakukan partisipasi terdorong (induced participation) yaitu, masyarakat memperoleh hak dalam pembagian keuntungan. Dalam tahap pelaksanaan, masyarakat lokal berpartisipasi sebagai guide lokal yang selalu di pakai oleh para tour operator yang datang bersama tamu nya dari luar Papua. Masyarakat lokal ikut berpartisipasi dikarenakan kawasan yang hendak dikunjungi adalah kawasan wisata yang baru bagi penyelenggara perjalanan. Oleh karena itu dibutuhkan masyarakat lokal yang dapat menjadi guide lokal untuk ikut menemani para tamu/wisatawan. Pada tahap pengambilan pemanfaatan, dalam usaha jasa pramuwisata, masyarakat lokal melakukan partisipasi terdorong (induced participation) yaitu, terdapat alternatif pilihan dari suatu usulan yang telah ditawarkan dan mendapatkan feedback dari masyarakat. Pada tahap pengambilan pemanfaatan, masyarakat lokal diberikan saran dan usulan beserta dengan kegiatan-kegiatan pelatihan dalam mengembangkan pengetahuan masyarakat lokal dalam bidang pramuwisata. Namun dalam pengambilan pemanfaatan ini tidak semua masyarakat lokal dapat mengaplikasikan apa yang telah mereka dapatkan. Di Kota Sentani terdapat kurang lebih 6 orang pramuwisata lokal. Jumlah ini memang lebih besar dari pramuwisata yang berasal dari luar daerah. Namun jika dilihat dari luas wilayah dan potensi wisata yang ada di Kota Sentani dan Kabupaten Jayapura pada umumnya, jumlah ini masih sangat kurang. Pada tahap evaluasi dalam usaha jasa pramuwisata, dapat diketahui bahwa masyarakat lokal melakukan partisipasi terdorong (induced participation) yaitu, terdapat alternatif pilihan dari suatu usulan yang telah ditawarkan dan mendapatkan feedback dari masyarakat. Pada tahap evaluasi dalam bidang pramuwisata masyarakat lokal yang telah mengikuti pelatihan pramuwisata yang diadakan pemerintah dapat mengaplikasikan pengetahuan yang ia dapatkan guna untuk membantu mengembangkan industri pariwisata di Kota Sentani dengan menjadi pramuwisata lokal yang berperan aktif. 


\section{Usaha pendukung (Penjual Souvenir)}

Berdasarkan hasil wawancara dengan Ibu Martha Ohee (Pengrajin Lukisan kulit kayu, Juni 2019), dapat diketahui bahwa dalam usaha pendukung (menjual souvenir) pada tahap pengambilan keputusan, masyarakat lokal berpartisipasi spontan yaitu, masyarakat lokal memiliki kesempatan untuk melakukan perencanaan dan bertanggung jawab mengatur serta memiliki wewenang sepenuhnya. Dalam usaha souvenir di Kota Sentani masyarakat lokal mempunyai kebebasan dalam mengambil keputusan baik untuk merencanakan maupun dalam menjalankan usaha handycraft nya. Pada tahap pelaksanaan, masyarakat lokal berpartisipasi spontan yaitu, partisipasi dilakukan secara langsung. Partipasi yang muncul telah ada bersifat bottom-up, partispasi aktif dan termasuk partisipasi asli. Dalam pelaksanaan usaha handycraft di Kota Sentani, masyarakat berpartisipasi langsung dalam menjalankan usaha handycraft nya di Kota Sentani tanpa diwakili oleh siapapun. Jika wisatawan ingin membeli oleh-oleh kerajinan tangan khas dari Kota Sentani, wisatawan bisa membeli langsung dari masyarakat lokal yang berjualan di Khalkote maupun di area Bandara Sentani. Pada tahap pengambilan pemanfaatan dalam usaha souvenir, dapat diketahui bahwa masyarakat lokal berpartisipasi spontan yaitu, masyarakat lokal memiliki kesempatan untuk melakukan perencanaan dan bertanggung jawab mengatur serta memiliki wewenang sepenuhnya. Pada pengambilan pemanfaatan dalam usaha ini, diketahui bahwa masyarakat lokal berpartisipasi aktif dalam memanfaatkan potensi yang mereka miliki dalam memproduksi dan menjalankan usaha handycraft yang kemudian dijual kepada wisatawan. Pada tahap evaluasi dalam usaha handycraft, dapat diketahui bahwa masyarakat lokal berpartisipasi spontan, yaitu, masyarakat lokal memiliki kesempatan untuk melakukan perencanaan dan bertanggung jawab mengatur serta memiliki wewenang sepenuhnya. Dalam evaluasi usaha handycraft, masyarakat lokal tetap memiliki kebebasan dalam pengembangan usaha handycraft yang mereka miliki tanpa dibatasi oleh pihak manapun.

\section{SIMPULAN DAN SARAN Simpulan}

Potensi pariwisata yang berada di Kota Sentani adalah Danau Sentani, Bukit
Teletubies, Danau Love, Air terjun Harapan, Desa wisata Asei, Monumen Tugu Mac.Arthur dan Cyckloop Waterpark. Masyarakat lokal Kota Sentani yang mempunyai usaha dalam bidang daya tarik wisata di Kota Sentani adalah sebesar $57 \%$, rent car $27 \%$, rent boat $100 \%$, jasa perjalanan wisata $25 \%$, restaurant $3.3 \%$, penyediaan akomodasi $17 \%$, jasa pramuwisata $60 \%$, handycraft kulit kayu $100 \%$. Dalam usaha daya tarik wisata di Kota Sentani dalam tahap pengambilan keputusan masyarakat berada pada partisipasi spontan. Dalam tahap pelaksanaan masyarakat lokal berada pada partisipasi spontan, dalam tahap pengambilan pemanfaatan masyarakat lokal berada pada partisipasi spontan, dan pada tahap evaluasi dalam usaha daya tarik wisata masyarakat lokal berada pada partisipasi terdorong (Induced Participation). Untuk partisipasi masyarakat lokal dalam usaha jasa transportasi wisata rent car di Kota Sentani pada tahap pengambilan keputusan partisipasi masyarakat lokal berapa pada partisipasi spontan, pada tahap pelaksanaan masyarakat lokal berada pada tahap partisipasi paksaan (Coersive Participation), pada tahap pengambilan pemanfaatan masyarakat lokal berada pada partisipasi paksaan (Coersive Participation), dan pada tahap evaluasi masyarakat lokal berada pada partisipasi terdorong (Induced Participation) . Pada tahap pengambilan keputusan, pelaksanaan, pengambilan pemanfaatan dan evaluasi dalam usaha rent boat dapat diketahui bahwa partisipasi masyarakat lokal berada pada tahap partisipasi spontan. Untuk partisipasi masyarakat lokal dalam usaha jasa perjalanan wisata, partisipasi masyarakat lokal dalam tahap pengambilan keputusan berada pada partisipasi spontan, pada tahap pelaksanaan dan pengambilan pemanfaatan partisipasi masyarakat lokal berada pada partisipasi paksaan (Coersive Participation), pada tahap evaluasi usaha jasa perjalanan wisata partispasi masyarakat lokal berada pada partisipasi terdorong (Induced Participation). Dalam usaha jasa makanan dan minuman, partisipasi masyarakat lokal pada tahap pengambilan keputusan berada pada partisipasi spontan, pada tahap pelaksanaan dan pengambilan pemanfaatan masyarakat lokal berada pada partispasi paksaan (Coersive Participation), dan pada tahap evaluasi partisipasi masyarakat lokal berada pada partisipasi terdorong (Induced Participation). 
Dalam usaha penyediaan akomodasi partisipasi masyarakat lokal dalam tahap pengambilan keputusan berada pada partisipasi spontan, pada tahap pelaksanaan dan pengambilan pemanfaatan partisipasi masyarakat lokal berada pada partisipasi paksaan (Coersive Participation), dan pada tahap evaluasi partisipasi masyarakat lokal berada pada partisipasi terdorong (Induced Participation). Dalam usaha jasa pramuwisata di Kota Sentani, partisipasi masyarakat lokal pada tahap pengambilan keputusan, pelaksanaan, pengambilan pemanfaatan dan evaluasi berada pada partisipasi terdorong (Induced Participation). Partisipasi masyarakat lokal dalam usaha wisata tirta di Kota Sentani pada tahap pengambilan keputusan, pelaksanaan dan pengambilan pemanfaatan berada pada partisipasi spontan, pada tahap evaluasi partisipasi masyarakat berada pada partisipasi terdorong (Induced Participation). Partisipasi masyarakat lokal dalam usaha handycraft di Kota Sentani pada tahap pengambilan keputusan, pelaksanaan, pengambilan pemanfaatan, dan evaluasi berada pada partisipasi spontan.

\section{Saran}

1. Agar lebih sering mengadakan kegiatan pelatihan-pelatihan dalam bidang usaha wisata guna untuk meningkatkan kualitas sumber daya manusia dalam bidang pariwisata di Kota Sentani.

2. Memberikan bantuan modal usaha kepada masyarakat lokal yang hendak memulai usaha dalam bidang pariwisata di Kota Sentani.

3. Lebih serius dalam perencanaan dan pengembangan pariwisata di Kota Sentani.

4. Agar dapat mengutamakan kepentingan masyarakat lokal dalam hal pengelolaan usaha-usaha wisata yang berada di Kota Sentani.

5. Melibatkan masyarakat lokal dalam memulai dan menjalankan suatu usaha wisata di Kota Sentani.

6. Agar dapat berusaha mengembangkan pengetahuan diri khususnya dalam bidang industri pariwisata.

7. Tetap menjaga keamanan dan kenyamanan disetiap daya tarik wisata yang ada di Kota Sentani.

8. Menjaga aset wisata yang ada di Kota Sentani agar tidak berpindah kepemilikannya kepada masyarakat pendatang maupun pengusaha yang berasal dari luar Kota Sentani dan Papua. 


\section{Kepustakaan}

Arnstein, S.R. 1969 (dalam Palimbunga, 2018) Keterlibatan masyarakat dalam pengembangan pariwisata di Desa Wisata Tabalanusu, Papua. Prodi Magister Kajian Pariwisata Universitas Udayana.

Cohen and Uphoff, 1997. Pural Development Participation Cornel University. New York : Cornel University RDCCIS

G Nagarjuna. 2015. Local Community Involvement in Tourism: A Content Analysis of Websites of Wildlife Resorts. Department of Tourism Studies, Indian Academy Group of Institutions, Bangalore. India

Meray Geraldy, Tilaar Sonny, Takumansang Esli. 2016. Partisipasi masyarakat terhadap pengembangan pariwisata Pantai Mahembang Kecamatan Kakas. Program Studi Perencanaan Wilayah \& Kota Universitas Sam Ratulangi Manado.

Muganda Michael, Sirima Agnes dan Peter Marwa. 2013. The Role of Local Communities in Tourism Development: Grassroots Perspectives from Tanzania. Department of Wildlife Management, Sokoine University of Agriculture, Morogoro Tanzania.

Muljadi. Warman Andri. 2014. Kepariwisataan dan Perjalanan. Jakarta : PT.Raja Grafindo Persada

Murniati. 2008. Partisipasi Masyarakat Dalam Pengembangan Desa Wisata (Studi Deskriptif Kualitatif Tentang Partisipasi Masyarakat Dalam Pengembangan Desa Wisata Di Desa Wirun Kecamatan Mojolaban Kabupaten Sukoharjo). Fakultas Ilmu Sosial Dan Ilmu Politik Universitas Sebelas Maret Surakarta.

Nisrina Aziz. 2018. Partisipasi Masyarakat Dalam Pembangunan Dan Pengembangan Objek Wisata Dam
Margotirto Di Desa Gisting Bawah Kecamatan Gisting Kabupaten Tanggamus. Fakultas Ilmu Sosial Dan Ilmu Politik Universitas Lampung Bandar Lampung.

Nur'anas Amanda. 2019. Partisipasi Masyarakat Dalam Pembangunan Desa Sangat Tertinggal (Studi Pekon Suka Mulya Kecamatan Pagar Dewa Kabupaten Lampung Barat). Fakultas Ilmu Sosial Dan Ilmu Politik Universitas Lampung. Bandar Lampung.

Palimbunga Pujiningrum Ika. 2018. Keterlibatan masyarakat dalam pengembangan pariwisata di Desa Wisata Tabalanusu, Papua. Prodi Magister Kajian Pariwisata Universitas Udayana.

Pitana, I.G., 2002. "Kebijakan dan Strategi Pemerintah Daerah Bali dalam Pembangunan Pariwisata. Pada Seminar Nasional Pariwisata Bali the Last or the Lost Paradise". Pembangunan Pariwisata yang Berkelanjutan. Denpasar: Universitas Udayana.

San Robertus, Karini Oka Ni Made, Mananda Sasrawan. 2016. Partisipasi Masyarakat Dalam Pengembangan Daya Tarik Wisata Pantai Pandawa, Kabupaten Badung, Desa Kutuh, Kuta Selatan. PS. S1 Industri Perjalanan Wisata Fakultas Pariwisata. Universitas Udayana. Bali

Tosun, C. dalam Darmayanti, Nugroho. 2018. Partisipasi Masyarakat Dalam Pengelolaan Daya Tarik Wisata Espa Yeh Panes Natural Hot Spring Resort Di Desa Penatahan Tabanan. Program Studi S1 Destinasi Pariwisata, Fakultas Pariwisata,Universitas Udayana. Bali

Undang-Undang dan Peraturan Pemerintah Nomor 10 Tahun 2009 Tentang Kepariwisataan. Pemerintah Republik Indonesia. 